\title{
X-Ray Diffraction and Vibrational Spectroscopic Characteristics of Hydroxylclinohumite from Ruby-Bearing Marbles (Luc Yen District, Vietnam)
}

\author{
V. Hurai, ${ }^{1}$ M. Wierzbicka-Wieczorek, ${ }^{2}$ M. Pentrák, ${ }^{3}$ M. Huraiová, ${ }^{4}$ R. Thomas, ${ }^{5}$ \\ A. Swierczewska, ${ }^{6}$ and J. Luptáková ${ }^{7}$ \\ ${ }^{1}$ Geological Institute, Slovak Academy of Sciences, Dubravska cesta 9, 84005 Bratislava, Slovakia \\ ${ }^{2}$ Mineralogy Department, Institute for Geosciences, Friedrich-Schiller University, 07745 Jena, Germany \\ ${ }^{3}$ Institute of Inorganic Chemistry, Slovak Academy of Sciences, 84005 Bratislava, Slovakia \\ ${ }^{4}$ Department of Mineralogy and Petrology, Comenius University, 84215 Bratislava, Slovakia \\ ${ }^{5}$ Helmholtz Center Geoforschungs Zentrum, 14473 Potsdam, Germany \\ ${ }^{6}$ AGH University of Science and Technology, Faculty of Geology, Geophysics and Environment Protection, 30-059 Krakow, Poland \\ ${ }^{7}$ Geological Institute, Slovak Academy of Sciences, 97401 Banská Bystrica, Slovakia \\ Correspondence should be addressed to V. Hurai; vratislav.hurai@savba.sk
}

Received 28 June 2013; Accepted 22 October 2013; Published 29 January 2014

Academic Editors: M. Arima, A. I. Becerro, J. Du, and B. Tsikouras

Copyright (c) 2014 V. Hurai et al. This is an open access article distributed under the Creative Commons Attribution License, which permits unrestricted use, distribution, and reproduction in any medium, provided the original work is properly cited.

\begin{abstract}
A honey-yellow hydroxylclinohumite from ruby-bearing marbles of the Luc Yen district in northern Vietnam was characterized by electron microprobe (EPMA), single-crystal X-ray diffraction (XRD), micro-Raman, and Fourier-transform infrared (FTIR) spectroscopy. The studied crystals correspond to nearly ideal clinohumite with the structural formula $4\left[\mathrm{Mg}_{2} \mathrm{SiO}_{4}\right] \cdot\left[(\mathrm{Mg}, \mathrm{Fe}, \mathrm{Ti})(\mathrm{OH}, \mathrm{F})_{2}\right]$ and roughly equal $\mathrm{F}$ and $\mathrm{OH}$ proportions. Crystal structure analysis showed Ti substitution for $\mathrm{Mg}$ only at the $\mathrm{Mg} 3$ site. A Fourierdifference map revealed one hydrogen site associated with ninth oxygen atom. The calculated $\mathrm{O}-\mathrm{H}$ bond distance was shorter than that in other natural clinohumites. FTIR revealed bands corresponding to combination of $\mathrm{OH}$-stretching with $\mathrm{Mg}-\mathrm{OH}$ and/or Fe$\mathrm{OH}$ bending modes, combinations of $\mathrm{OH}^{-}$and $\mathrm{Fe}-\mathrm{OH}$ vibrations, combination of fundamental bands of the $\mathrm{Si}-\mathrm{OH}$ bonding, combination of $\mathrm{OH}^{-}$and $\mathrm{Si}-\mathrm{OH}$ vibrations, and first $\left(2 v_{\mathrm{OH}}\right)$ and the second $\left(3 v_{\mathrm{OH}}\right)$ overtones of the $\mathrm{OH}$-stretching vibration mode. Two groups of $\mathrm{OH}$-stretching vibration and FTIR absorption bands at $3390-3420 \mathrm{~cm}^{-1}$ and $3560-3580 \mathrm{~cm}^{-1}$ show reversible temperature-dependent shift. The low-frequency bands absent in pure synthetic hydroxylclinohumites are assigned to $\mathrm{OH}$-planar defects caused by Ti-for-Mg substitution.
\end{abstract}

\section{Introduction}

Humite-group minerals have the general formula $n\left(M_{2} \mathrm{SiO}_{4}\right)$ $M_{1-x} \mathrm{Ti}_{x}(\mathrm{OH}, \mathrm{F})_{2-2 x} \mathrm{O}_{2 x}$, where $M$ stands for $\mathrm{Mg}, \mathrm{Fe}, \mathrm{Mn}$, $\mathrm{Ca}, \mathrm{Zn}$ in decreasing order of abundance, $x<0.5$ and $n$ numbers from 1 to 4 define norbergite, chondrodite, humite and clinohumite, respectively [1]. The humite-group minerals have attracted attention owing to the suspicion of being volatile carriers in subduction zones and the overlying mantle wedge. This hypothesis was strengthened by occurrences of chondrodite and clinohumite in eclogite, garnet peridotite [2-5], and kimberlite [6], as well as by the experimentally proven stability of these minerals at high- $P T$ conditions $[7,8]$. In addition, the humite-group minerals are typical of the carbonates metamorphosed under high pressure and/or temperature [9-15]. Humite-like defects ( $\mathrm{OH}$-bearing monolayers) were discovered in nominally anhydrous mantle olivine $[16,17]$ and the assignment of the specific IR absorption bands in olivines to the clinohumite-like point and planar defects has been a matter of extensive ongoing research [18-20].

In spite of their importance for estimating the amount of water in the upper mantle, interpretation of the vibrational and absorption spectra of the humite-group minerals remains inconclusive, partly due to their complexity and partly due to 


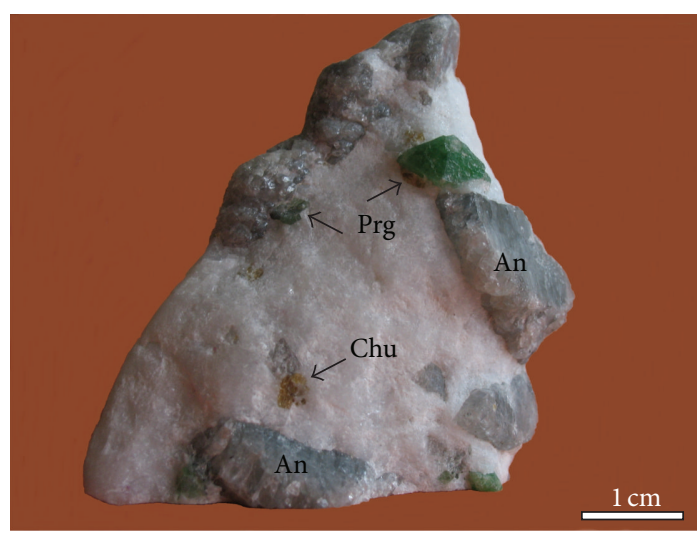

(a)

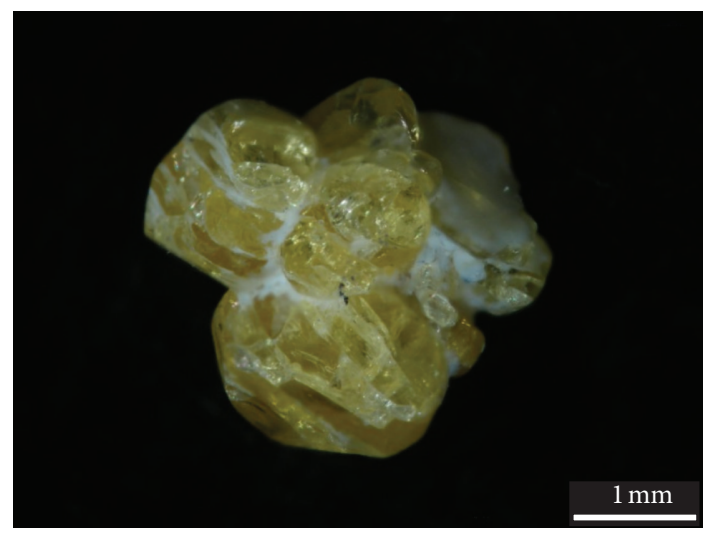

(b)

FIGURE 1: (a) Honey-yellow crystals of hydroxylclinohumite (Chu) associated with grey anorthite (An) and green pargasite (Prg) in white calcite matrix. (b) Aggregate of hydroxylclinohumite crystals isolated after dissolution of calcite matrix in hydrochloric acid.

incomplete, erratic, or even missing chemical and structural characteristics of the studied samples. For instance, Frost et al. $[21,22]$ interchanged sampling sites of clinohumite and $\mathrm{Ti}$ clinohumite in two companion papers. Their "clinohumite" with 7.35 a.p.f.u. (atoms per formula unit) $\mathrm{Mg}, 0.5$ a.p.f.u. $\mathrm{Ca}$, and 0.13 a.p.f.u. Fe exhibits deficiency of divalent cations needed for creating the olivine- and brucite-like layers. Moreover, an extremely high aluminium content ( 0.45 a.p.f.u. $\mathrm{Al}$ ) cannot be allocated in the clinohumite crystal structure.

Yang and Keppler [20] have shown that structural models of water dissolution in olivine derived from infrared spectra at atmospheric conditions may not be fully applicable for the mantle, because some important $\mathrm{OH}$-absorption bands disappear at low temperatures. Until recently, only absorption spectra of synthetic Ti- and F-poor clinohumite and chondrodite have been studied at temperatures up to $600^{\circ} \mathrm{C}$ and pressures to $29 \mathrm{kbar}[23,24]$, whilst similar experiments with natural minerals are missing. Hence, the main intention of this work is to fill partially the gaps outlined above by providing the set of complementary EPMA, XRD, Raman, and FTIR data on natural clinohumite from Vietnam. An additional benefit of this contribution results from the fact that though the Vietnamese gem-quality clinohumite is frequently offered in internet auctions, it has not been hitherto described in the mineral assemblage of the ruby-bearing marbles, where it occurs [25]. Hence, Raman and FTIR records from single crystals presented in this study would yield the reference basis for a nondestructive identification of the clinohumite in jewellery. Special attention will be paid to annealing experiments, which are expected to provide evidence on the nature of $\mathrm{OH}$-absorption bands in natural clinohumite applicable also to hydrated olivine.

\section{Materials and Methods}

2.1. Geological Background. The mineral studied is represented by honey-yellow crystals with rounded corners, up to $5 \mathrm{~mm}$ in diameter, associated with grey anorthite and green pargasite-edenite embedded in calcite matrix (Figure 1). The hand specimen comes from the Cambrian marble unit of the Luc Yen mining district in Vietnam, belonging to the most important sources of high quality gem rubies and sapphires in Southeast Asia. The mining district is situated along the north-eastern flank of the Day Nui Con Voi Range in the Red River Shear Zone [26]. The origin of the ruby and the associated assemblage is linked to the activity of the Red River shear zone between 35 and 40 Ma coincidental with the deformation of Asian plate after collision with India (Himalayan orogeny). Gem ruby deposits originated during retrograde metamorphic path at temperatures of $620-670^{\circ} \mathrm{C}$ and a $2.6-$ $3.3 \mathrm{kbar}$ pressure in the presence of evaporites, which played a key-role in their formation [27, 28]. Microscopic and electron microprobe investigation of thin sections from the studied sample revealed also graphite, pyrrhotite, chalcopyrite, pyrite, muscovite, phlogopite, margarite, clinochlore, titanite, rutile, dolomite, ankerite, spinel, thorianite, fluorapatite, forsterite, zircon, ruby, and sapphire [29].

2.2. Analytical Methods and Techniques. Chemical composition was determined using a CAMECA SX-100 electron microprobe (State Geological Institute of Dionýz Štúr, Bratislava, Slovakia) in WDS mode and standard operating conditions: $15 \mathrm{keV}$ accelerating voltage, $20 \mathrm{nA}$ beam current, 5-10 $\mu \mathrm{m}$ beam diameter. Calibration was made using natural and synthetic minerals (main element line, crystal used, and detection limit in wt.\% in parentheses): $\mathrm{Si}$-wollastonite (K $\alpha$, TAP, 0.02), $\mathrm{Cl}$-halite (K $\alpha$, LPET, 0.01), K-orthoclase (K $\alpha$, LPET, 0.01), Ca-wollastonite (K $\alpha$, LPET, 0.01), $\mathrm{Mg}-$ forsterite (K $\alpha$, TAP, 0.02), Fe-fayalite (K $\alpha$, LLIF, 0.06), Mn-

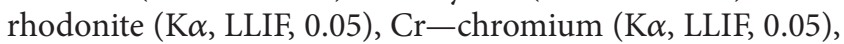
$\mathrm{Ni}-$ nickel (K $\alpha$, LLIF, 0.08), $\mathrm{Ti}-\mathrm{TiO}_{2}$ ( $\mathrm{K} \alpha$, LPET, 0.02), and $\mathrm{F}-\mathrm{LiF}(\mathrm{K} \alpha, \mathrm{LPC} 0,0.09)$. Raw analyses were recalculated to weight percents of oxides using a standardized PAP correction [30].

A Nonius Kappa APEX II single-crystal X-ray diffractometer with graphite-monochromated $\mathrm{MoK} \alpha$ radiation (Institute of Inorganic and Analytical Chemistry, FriedrichSchiller University, Jena, Germany) was used to collect 
intensity data from a single crystal at $-120^{\circ} \mathrm{C}$. Data were corrected for Lorentz, polarization effects, and background, but not for absorption effects [31, 32]. The crystal structure was refined by full-matrix least-squares techniques on $F^{2}$ in the nonstandard space-group setting $P 2_{1} / b 11$ (atomic coordinates and anisotropic displacement parameters for the non-H-atoms; SHELXL-97 [33]). The atomic coordinates of clinohumite given by Friedrich et al. [34], excluding the $\mathrm{H}$ atom, served in the starting set for the structure refinement.

Raman spectra were recorded with Horiba Jobin-Yvon LabRam HR800 spectrometers (Helmholtz Centre GFZ, Potsdam, Germany, and Geological Institute SAS, Banská Bystrica, Slovakia) at room temperature and pressure. The spectrometers with $1800 \mathrm{gr} / \mathrm{mm}$ gratings were equipped with an Olympus optical microscope. Crystals were irradiated using a $488 \mathrm{~nm}$ laser excitation of a Coherent Innova 70 $\mathrm{Cr}^{+}$ laser with a power of $300 \mathrm{~mW}$ (about $14 \mathrm{~mW}$ on sample) and with a $633 \mathrm{~nm}, 17 \mathrm{~mW}$ LHX1 CVI Melles Griot He-Ne laser. A long-working-distance LMPLanFI $100 \times / 0.8$ objective was used for focusing the laser beam and collecting the scattered light. The focused laser spot on the sample was $\sim 1 \mu \mathrm{m}$ in diameter. The spectra were collected at $20^{\circ} \mathrm{C}$ with a Peltiercooled $\left(-70^{\circ} \mathrm{C}\right)$ multichannel CCD detector $(1024 \times 256$ pixels) in two separate regions, at $70-1100 \mathrm{~cm}^{-1}$ and $2600-$ $4000 \mathrm{~cm}^{-1}$. Maximum spectral resolutions corresponded to $0.4 \mathrm{~cm}^{-1}$ using the $488 \mathrm{~nm}$ laser excitation and $0.3 \mathrm{~cm}^{-1}$ for the $633 \mathrm{~nm}$ laser excitation. Positions of the Raman bands were controlled according to principal plasma lines of the argon laser and neon glow lamp. The difference between recommended and measured line positions was less than $0.6 \mathrm{~cm}^{-1}$.

FTIR spectra in the middle infrared (MIR) region (4000$400 \mathrm{~cm}^{-1}$ ) were recorded using a Nicolet 6700 spectrometer equipped with a KBr beam splitter and KBr DTGS detector at Institute of Inorganic Chemistry, Slovak Academy of Sciences, Bratislava, Slovakia. The KBr-pressed disc technique (1 mg of sample mixed with $200 \mathrm{mg}$ of $\mathrm{KBr}$ ) and a Smart Orbit, high-performance diamond single-bounce ATR accessory, were used. The $\mathrm{KBr}$ discs were heated at $150^{\circ} \mathrm{C}$ for 12 hours to minimize the content of adsorbed water. For each sample, 128 scans with a resolution of $4 \mathrm{~cm}^{-1}$ were recorded. For the near infrared (NIR) region (12000$4000 \mathrm{~cm}^{-1}$ ), a $\mathrm{CaF}_{2}$ beam splitter, an InGaAs detector, and a Smart Diffuse Reflectance (DRIFT) accessory were used to obtain spectra from $\mathrm{KBr}$ discs and single clinohumite crystals. Finally, MIR spectra were obtained from powdered clinohumite put into the DRIFT accessory equipped with an environmental chamber purged with nitrogen gas and heated under controlled temperature up to $900^{\circ} \mathrm{C}$. A total of 256 scans with a resolution of $2 \mathrm{~cm}^{-1}$ were recorded in this mode. Spectral treatment was performed using the OMNIC software package (Nicolet Instruments Corp).

Frequencies of Raman and FTIR bands were obtained by curve-fitting procedures provided with the Peakfit software, version 4.12, from the SeaSolve Software Inc., USA. Band fitting was done using a Gauss-Lorentz area cross-product function, Savitsky-Golay or FFT smoothing algorithms, and a minimum number of component bands. The residuals
TABLE 1: Average composition and chemical formula of hydroxylclinohumite from Vietnam.

\begin{tabular}{lccc}
\hline Oxide & wt. $\%$ & Ion & Average a.p.f.u. \\
\hline $\mathrm{SiO}_{2}$ & $38.5(1)$ & $\mathrm{Si}^{4+}$ & 3.997 \\
$\mathrm{TiO}_{2}$ & $0.52(3)$ & $\mathrm{Ti}^{4+}$ & 0.041 \\
$\mathrm{MgO}$ & $57.6(2)$ & $\mathrm{Mg}^{2+}$ & 8.911 \\
$\mathrm{FeO}$ & $0.48(2)$ & $\mathrm{Fe}^{2+}$ & 0.042 \\
$\mathrm{~F}$ & $2.89(8)$ & $\mathrm{F}^{-}$ & 0.948 \\
$\mathrm{O}=\mathrm{F}$ & $-1.22(3)$ & & \\
$\mathrm{H}_{2} \mathrm{O}^{*}$ & $1.52(3)$ & $\mathrm{OH}^{-*}$ & 1.052 \\
\hline Total & $100.3(3)$ & &
\end{tabular}

a.p.f.u.: atoms per formula unit; numbers in parentheses are standard deviations $(1 \sigma)$ referred to last decimal digit.

${ }^{*} \mathrm{OH}=2-\mathrm{F}, \mathrm{H}_{2} \mathrm{O}$ content back-calculated from the calculated $\mathrm{OH}$ content, other elements ( $\mathrm{Na}, \mathrm{K}, \mathrm{Ca}, \mathrm{Al}, \mathrm{Mn}, \mathrm{Cr}, \mathrm{Ni}, \mathrm{Ca}$, and $\mathrm{Cl}$ ) below detection limits.

method enabled visualisation of hidden peaks. The fitting was repeated until the convergence was reached at squared correlations of $r^{2}$ goodness better than 0.995 .

\section{Results}

3.1. Chemical Composition. EPMA analyses recalculated on basis of 13 cations and 18 oxygen atoms (Table 1 ) document nearly complete occupancy of tetrahedral site with Si (3.996-4.000 a.p.f.u). The surplus titanium (0.0380.039 a.p.f.u.) over the negligible tetrahedrally coordinated $\mathrm{Ti}$ (max. 0.004 a.p.f.u.) together with the Mg-excess over tetrahedrally coordinated $\mathrm{Mg}$ (0.907-0.917 a.p.f.u.), plus minor amounts of $\mathrm{Fe}$ (0.040-0.043 a.p.f.u.) and Mn (0.002 a.p.f.u.) sum to 1 atom per formula unit (a.p.f.u.) in the octahedrally coordinated $M$-site, thus resulting in the nearly ideal chemical formula $4\left[\mathrm{Mg}_{2} \mathrm{SiO}_{4}\right] \cdot\left[(\mathrm{Mg}, \mathrm{Fe}, \mathrm{Ti})(\mathrm{OH}, \mathrm{F})_{2}\right]$ with $n=4$ that is diagnostic of clinohumite. Predominance of $\mathrm{OH}( \pm \mathrm{O})$ over F points to hydroxylclinohumite; however, the exact $\mathrm{F} / \mathrm{OH}$ ratio remains uncertain due to the unknown content of oxygen anions, which may reach up to $\sim 0.08$ a.p.f.u., assuming their bonding with octahedrally coordinated $\mathrm{Ti}[1]$, and also due to the matrix effect on the $\mathrm{F}$ concentrations analysed in the silicate mineral using the LiF standard [35].

3.2. Crystal Structure. The hydroxylclinohumite crystal studied exhibited good quality, with no evidence of twinning or other unusual features. The final structural refinement yielded $R 1(F)=1.98 \%$ for 1354 "observed" reflections and 150 parameters (Table 2). The highest residual electron-density peak in clinohumite corresponds to $0.39 \mathrm{e} / \AA^{3}$ at a distance of $0.81 \AA$ from the 01,1 site. The deepest hole in the difference map is $-0.28 \mathrm{e} / \AA^{3}$ at a distance of $0.68 \AA$ from the Sil site. The final displacement parameters are given in Table 3 , whereas Table 4 contains anisotropic displacement parameters for all non-H atoms. Finally, selected bond lengths and results of bond-valence calculations (bond-valence sums, BVS, in valence units, v.u.) are summarized in Table 5.

The crystal structure of the studied clinohumite consists of isolated $\mathrm{SiO}_{4}$ tetrahedra and octahedrally coordinated 
TABLE 2: Crystal data, data-collection information, and refinement details.

\begin{tabular}{lc}
\hline Crystal data & $\left(\mathrm{Mg}_{8.95} \mathrm{Ti}_{0.05}\right)\left(\mathrm{SiO}_{4}\right)_{4} \mathrm{~F}_{1.03} \mathrm{OH}_{0.97}$ \\
Formula & 624.41 \\
Molecular weight & Canary-yellow \\
Colour & Monoclinic \\
Crystal system & $P 2_{1} / b, 2$ \\
Space group, $Z$ & $10.231(2), 13.644(3)$ \\
$a, b, c(\AA)$ at $153 \mathrm{~K}^{*}$ & $100.82(3)$ \\
$\alpha\left(^{\circ}\right)$ at $153 \mathrm{~K}$ & $649.9(2)$ \\
$V\left(\AA^{3}\right)$ & $620,3.19$ \\
$F(000), \rho_{\text {calc }}\left(\mathrm{g} / \mathrm{cm}^{3}\right)$ & 1.1 \\
$\mu\left(\mathrm{mm}{ }^{-1}\right)$ & $0.10 \times 0.09 \times 0.07$ \\
Crystal dimension $(\mathrm{mm})$ & \\
\hline Data Collection & $\mathrm{NONIUS} \mathrm{KAPPA} \mathrm{APEX} \mathrm{II}$ \\
Diffractometer & $0.71069,153$ \\
$\lambda($ MoK $\alpha)(\AA), T(\mathrm{~K})$ & 33.2 \\
Crystal-detector dist. $(\mathrm{mm})$ & sphere, 54.2 \\
Collection mode, $2 \theta_{\text {max }}\left({ }^{\circ}\right)$ & $\varphi, \omega, 1$ \\
Rotation axis, width $\left(^{\circ}\right)$ & 288 \\
Total no. of frames & 17 \\
Collect. time per degree $(\mathrm{s})$ & $-6 / 5,-12 / 13,-15 / 17$ \\
$h, k, l$ ranges & 3546 \\
Total reflections measured & $1426\left(R_{\text {int }} 2.16 \%\right)$ \\
Unique reflections & \\
\hline Refinement & \\
\hline &
\end{tabular}

Refinement

Refinement method

Weighting coefficients $a, b^{* *}$

Full-matrix least-squares on $F^{2}$ $0.0161,0.3314$

150

No. of refined parameters

$R 1(F), w R 2\left(F^{2}\right)_{\text {all }}$

"Observed" refls.

Extinction coefficient

$1.98 \%, 4.95 \%$

GooF

$1354\left[F_{o}>4 \sigma\left(F_{o}\right)\right]$

$0.0563(18)$

1.134

$\Delta \rho_{\min }, \Delta \rho_{\max }\left(e / \AA^{3}\right)$

$-0.282,0.391$

$R_{\text {int }}=\Sigma\left[F_{o}^{2}-F_{o}^{2}\right.$ (mean) $] / \Sigma F_{o}^{2}, R 1=\Sigma|| F_{o}|-| F_{c}|| / \Sigma\left|F_{o}\right| ; w R 2=$ $\left\{\Sigma\left[w\left(F_{o}^{2}-F_{c}^{2}\right)^{2}\right] / \Sigma\left[w\left(F_{o}^{2}\right)^{2}\right]\right\}^{1 / 2}$.

${ }^{*}$ unit cell parameters at $25^{\circ} \mathrm{C}$ are as follows: $a=4.7479(9), b=10.2387(20)$, $c=13.6480(27)$, and $\alpha=100.89(3)^{\circ}$.

${ }^{* *} w=1 /\left[\sigma^{2}\left(F_{o}^{2}\right)+(a P)^{2}+b P\right]$, where $P=\left(\max \left(F_{o}^{2}, 0\right)+2 F_{c} 2\right) / 3$.

GooF $=\left\{\Sigma\left[w\left(F_{o}^{2}-F_{c}^{2}\right)^{2}\right] /(n-p)\right\}^{1 / 2}$, where $n$ is number of reflections and $p$ is number of refined parameters.

$\mathrm{Mg}^{2+}$ cations (Figure 2). The $\mathrm{Mg}^{2+}$ cations are characterized by five different octahedral sites: $M(1)_{c}$ and $M(2)_{6}$ are like those in olivines and $M(1)_{N}, M(2)_{6}$, and $M(3)$ are like those in humite [36]. The edge-sharing octahedra form zig-zag chains along the $c$-axis, separated by Sil- and Si2-centred tetrahedra. The linkage of $\mathrm{SiO}_{4}$ tetrahedra to $\mathrm{Mg}_{5}{ }^{-}$and $\mathrm{Mg} 2_{6}$-centred octahedra, which decorate the chain, results in their distortions. The long bond distances along this chain are $2.209 \AA$ for $\mathrm{Mg}_{2}-\mathrm{O} 2,4$ and $2.234 \AA$ for $\mathrm{Mg}_{2}-\mathrm{O} 1,4$.

Previous studies have either found hydrogen atoms in two different positions [37], at one site [38] or none at all [36]. Our Fourier-difference map shows only one $\mathrm{H}$

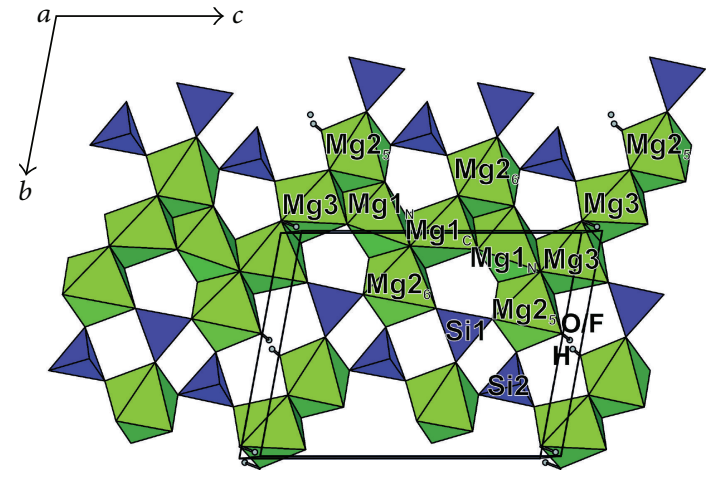

FIGURE 2: Crystal structure of hydroxylclinohumite from Vietnam generated by XtalDraw module [60]. Shown is a half of the unit cell viewed along $c$-axis.

site with the atomic coordinates similar to that described by Friedrich et al. [34] and Platonov et al. [39]. The site occupancy of the hydrogen atom was fixed to that of the respective donor oxygen atom $(47.7 \%)$. Refinements of the scattering power of all five $\mathrm{Mg}$ sites indicated a Ti-for-Mg substitution only at the $\mathrm{Mg} 3$ site, with $2.4 \%$ of the $\mathrm{Mg} 3$ site being occupied by $\mathrm{Ti}^{4+}$. The substitution previously described by Kocman and Rucklidge [40] and Fujino and Takéuchi [38] involves anion replacement of $\mathrm{O}^{2-}$ for $(\mathrm{F}, \mathrm{OH})^{-}$to yield the formula: $\mathrm{Mg}_{8} \mathrm{Si}_{4} \mathrm{O}_{16} \mathrm{Mg}_{0.95} \mathrm{Ti}_{0.05}(\mathrm{~F}, \mathrm{OH})_{1.9} \mathrm{O}_{0.1}$. The replacement of $(\mathrm{OH})$ by $\mathrm{F}$ or $\mathrm{Mg}$ by $\mathrm{Ti}$ stabilizes the crystal structure [38]. Electron probe analyses show a small amount of $\mathrm{Fe}(0.042$ a.p.f.u.). It is possible that this small $\mathrm{Fe}$ content is distributed among all five $\mathrm{MgO}_{6}$ octahedra, but this cannot be supported by the refinement.

Our structural refinement showed the hydroxylclinohumite from Vietnam to exhibit the $\mathrm{OH} \rightarrow \mathrm{F}$ substitution. More than $50 \%$ of the available oxygen sites are occupied by fluorine atoms (refined $\mathrm{O}: \mathrm{F}$ ratio $=0.477(4): 0.523(4)$ ). The discrepancy between minimal refined predominance of fluorine over hydroxide $\left(\mathrm{F}_{1.03} \mathrm{OH}_{0.97}\right)$ compared to the electron microprobe analyses $\left(\sim \mathrm{F}_{0.95} \mathrm{OH}_{1.05}\right)$ could result from measurement inaccuracy, matrix effect on EPMA analyses of fluorine [35], and/or minor chemical zonation. Considering all of these factors, the agreement between the structural and EPMA data is excellent.

The $\mathrm{OH} \rightarrow$ F substitution influences the intra-polyhedral bond distances of $\mathrm{Mg} 3 / \mathrm{Ti} 3-\mathrm{O} / \mathrm{F} \quad(2.0197(10) \AA$ and 2.0393(10) $\AA$ ) and $\mathrm{Mg}_{5}-\mathrm{O} / \mathrm{F}$ (2.0572(11) $\AA$ ) as well as the inter-polyhedral angle of $\mathrm{Mg} 2_{5}-\mathrm{O} / \mathrm{F}-\mathrm{Mg} 3 / \mathrm{Ti} 3\left(130.66^{\circ}\right)$. Compared to the F-free Ti-clinohumite from Val Malenco [34], these bond distances are longer, that is, 2.035(2) $\AA$ and 2.070(2) $\AA, 2.059(2) \AA$, respectively, as expected from a weaker $\mathrm{Mg} / \mathrm{Ti}-\mathrm{F}$ bond. The mentioned inter-polyhedral angle is slightly smaller $\left(128.7^{\circ}\right)$. Friedrich et al. [34] described other F-bearing Ti-clinohumite from Kuh-i-Lal (Pamir Mts.), where the $\mathrm{O}: \mathrm{F}$ ratio is inverse to that in our sample [0.516:0.484], while the intrapolyhedral bond distances and angle are comparable with those in our sample (2.030(2) $\AA$ and 2.050(2) $\AA, 2.057(2) \AA$ and $129.85^{\circ}$, resp.). 
TABLE 3: Fractional atomic coordinates and equivalent isotropic atomic displacement parameters for $\left(\mathrm{Mg}_{8.95} \mathrm{Ti}_{0.05}\right)\left(\mathrm{SiO}_{4}\right)_{4} \mathrm{~F}_{1.03} \mathrm{OH}_{0.97}$ hydroxylclinohumite.

\begin{tabular}{|c|c|c|c|c|}
\hline Atom & $x$ & $y$ & $z$ & $U_{\text {equiv }}{ }^{*}$ \\
\hline $\mathrm{Mgl}_{\mathrm{C}}$ & 0.5 & 0.0 & 0.5 & $0.00564(15)$ \\
\hline$M g 1_{N}$ & $0.49754(8)$ & $0.94627(4)$ & $0.27411(3)$ & $0.00572(13)$ \\
\hline $\mathrm{Mg}_{5}$ & $0.00935(9)$ & $0.14027(4)$ & $0.17013(3)$ & $0.00623(13)$ \\
\hline $\mathrm{Mg}_{6}$ & $0.50902(9)$ & $0.25031(4)$ & $0.38821(3)$ & $0.00543(13)$ \\
\hline $\mathrm{Mg} 3^{* * *}$ & $0.49278(9)$ & $0.87792(5)$ & $0.04300(3)$ & $0.00673(16)$ \\
\hline Sil & $0.07336(7)$ & $0.06623(3)$ & $0.38929(3)$ & $0.00437(12)$ \\
\hline $\mathrm{Si} 2$ & $0.07655(7)$ & $0.17671(3)$ & $0.83517(3)$ & $0.00443(12)$ \\
\hline $\mathrm{O} 1,1$ & $0.73316(19)$ & $0.06463(9)$ & $0.38804(6)$ & $0.0061(2)$ \\
\hline $\mathrm{O} 1,2$ & $0.27828(19)$ & $0.41986(9)$ & $0.38785(6)$ & $0.00578(19)$ \\
\hline $\mathrm{O} 1,3$ & $0.22309(19)$ & $0.11231(9)$ & $0.29332(7)$ & $0.0067(2)$ \\
\hline $\mathrm{O} 1,4$ & $0.22211(19)$ & $0.15865(9)$ & $0.48625(7)$ & $0.0067(2)$ \\
\hline $\mathrm{O} 2,1$ & $0.23638(19)$ & $0.32266(9)$ & $0.16264(6)$ & $0.0061(2)$ \\
\hline $\mathrm{O} 2,2$ & $0.77894(19)$ & $0.96858(9)$ & $0.16240(7)$ & $0.0063(2)$ \\
\hline $\mathrm{O} 2,3$ & $0.72441(19)$ & $0.27995(9)$ & $0.26242(7)$ & $0.0066(2)$ \\
\hline $\mathrm{O} 2,4$ & $0.72798(19)$ & $0.22672(9)$ & $0.07007(7)$ & $0.0065(2)$ \\
\hline $\mathrm{F}^{* * *}$ & $0.26229(19)$ & $0.04631(8)$ & $0.05580(6)$ & $0.0093(2)$ \\
\hline $\mathrm{H}^{* * *}$ & $0.090(10)$ & $0.020(5)$ & $0.013(4)$ & $0.050^{* *}$ \\
\hline
\end{tabular}

* According to Fischer and Tillmanns [57].

** Fixed in the refinement.

*** Occupancy: $\mathrm{Mg} 3 / \mathrm{Ti} 3=\mathrm{Mg}_{0.976(2)} \mathrm{Ti}_{0.024(2)}, \mathrm{O} / \mathrm{F}=\mathrm{O}_{0.477(4)} \mathrm{F}_{0.523(4)}, \mathrm{H}=\mathrm{H}_{0.477(4)}$.

TABLE 4: Anisotropic atomic displacement parameters for $\left(\mathrm{Mg}_{8.95} \mathrm{Ti}_{0.05}\right)\left(\mathrm{SiO}_{4}\right)_{4} \mathrm{~F}_{1.03} \mathrm{OH}_{0.97}$ hydroxylclinohumite.

\begin{tabular}{lcccccc}
\hline Atom & $U_{11}$ & $U_{22}$ & $U_{33}$ & $U_{23}$ & $U_{13}$ \\
\hline $\mathrm{Mgl}_{\mathrm{C}}$ & $0.0051(3)$ & $0.0070(3)$ & $0.0048(3)$ & $0.0012(2)$ & $-0.0007(2)$ & $0.0001(2)$ \\
$\mathrm{Mg}_{\mathrm{N}}$ & $0.0051(2)$ & $0.0065(3)$ & $0.0048(2)$ & $-0.00077(19)$ & $0.00052(16)$ & $0.00049(16)$ \\
$\mathrm{Mg}_{5}$ & $0.0064(2)$ & $0.0058(2)$ & $0.0064(2)$ & $0.00124(18)$ & $-0.00029(16)$ & $0.00011(15)$ \\
$\mathrm{Mg}_{6}$ & $0.0061(2)$ & $0.0047(2)$ & $0.0052(2)$ & $-0.00007(18)$ & $-0.00007(16)$ & $-0.00020(15)$ \\
$\mathrm{Mg}^{*}$ & $0.0069(3)$ & $0.0075(3)$ & $0.0052(2)$ & $-0.00009(17)$ & $-0.00055(16)$ & $0.00045(16)$ \\
$\mathrm{Si}{ }^{*}$ & $0.00355(19)$ & $0.00490(19)$ & $0.00443(19)$ & $0.00031(13)$ & $-0.00003(12)$ & $-0.00004(12)$ \\
$\mathrm{Si} 2$ & $0.00379(19)$ & $0.00483(19)$ & $0.00448(19)$ & $0.00038(14)$ & $0.00002(12)$ & $-0.00009(12)$ \\
$\mathrm{O} 1,1$ & $0.0048(4)$ & $0.0068(4)$ & $0.0063(4)$ & $0.0004(3)$ & $0.0001(3)$ & $0.0001(3)$ \\
$\mathrm{O} 1,2$ & $0.0059(4)$ & $0.0057(4)$ & $0.0056(4)$ & $0.0008(3)$ & $0.0004(3)$ & $-0.0001(3)$ \\
$\mathrm{O} 1,3$ & $0.0056(4)$ & $0.0082(4)$ & $0.0063(4)$ & $0.0015(3)$ & $-0.0003(3)$ & $-0.0002(3)$ \\
$\mathrm{O} 1,4$ & $0.0057(4)$ & $0.0069(4)$ & $0.0068(4)$ & $-0.0004(3)$ & $-0.0009(3)$ & $-0.0003(3)$ \\
$\mathrm{O} 2,1$ & $0.0047(4)$ & $0.0071(4)$ & $0.0063(4)$ & $0.0008(3)$ & $-0.0001(3)$ & $-0.0001(3)$ \\
$\mathrm{O} 2,2$ & $0.0061(4)$ & $0.0058(4)$ & $0.0066(4)$ & $0.0004(3)$ & $0.0002(3)$ & $0.0005(3)$ \\
$\mathrm{O} 2,3$ & $0.0059(4)$ & $0.0080(4)$ & $0.0063(4)$ & $0.0024(3)$ & $0.0000(3)$ & $0.0004(3)$ \\
$\mathrm{O} 2,4$ & $0.0061(4)$ & $0.0072(4)$ & $0.0055(4)$ & $-0.0003(3)$ & $0.0006(3)$ & $0.0002(3)$ \\
$F^{*}$ & $0.0102(4)$ & $0.0078(4)$ & $0.0098(4)$ & $0.0013(3)$ & $0.0025(3)$ & $0.0009(3)$ \\
\hline
\end{tabular}

* Occupancy: $\mathrm{Mg} 3 / \mathrm{Ti} 3=\mathrm{Mg}_{0.976(2)} \mathrm{Ti}_{0.024(2)}, \mathrm{O} / \mathrm{F}=\mathrm{O}_{0.477(4)} \mathrm{F}_{0.523(4)}$.

The average $\mathrm{Si}-\mathrm{O}$ bond length is $1.633 \AA$ in both $\mathrm{SiO}_{4}$ tetrahedra. The hydrogen site is associated with the "ninth" oxygen atom (labeled $\mathrm{O} / \mathrm{F}$ here) and occupies about half (47.7\%) of the general position. The $\mathrm{O}-\mathrm{H}$ and $\mathrm{H} \cdots \mathrm{H}$ bond distances correspond to 0.99(4) $\AA$, and $1.018 \AA$ respectively.

Calculated BVS for the $\mathrm{Mg}$ and $\mathrm{Si}$ sites are close to expected values: $2.02\left(\mathrm{Mg}_{\mathrm{C}}\right) / 1.99,\left(\mathrm{Mg}_{\mathrm{N}}\right) / 1.91,\left(\mathrm{Mg}_{5}\right) / 1.88$, $\left(\mathrm{Mg}_{6}\right) / 2.08(\mathrm{Mg} 3)$, and $3.90(\mathrm{Si} 1) / 3.91(\mathrm{Si} 2)$. As expected from the small Ti content in the Mg3 site, this site shows the highest calculated BVS (2.08 v.u.) among all five Mg sites. The relatively low BVS for $\mathrm{Mg} 2_{5}$ and $\mathrm{Mg} 2_{6}$ are explained in terms of long $\mathrm{Mg}-\mathrm{O}$ distances of the distorted octahedra. The BVS values for $\mathrm{O}$ bonds from $\mathrm{O} 1,1$ to $\mathrm{O} 2,4$ are consistent with those reported by Ferraris et al. [37]. The O/F anion with a BVS of 1.10 is underbonded, which results from the $55 \%$ F-for-O substitution. 
TABLE 5: Selected geometric parameters $(\AA)$ and calculated bond-valence sums (BVS) for the coordination polyhedra in $\left(\mathrm{Mg}_{8.95} \mathrm{Ti}_{0.05}\right)\left(\mathrm{SiO}_{4}\right)_{4} \mathrm{~F}_{1.03} \mathrm{OH}_{0.97}$ hydroxylclinohumite.

\begin{tabular}{|c|c|c|}
\hline Atom1-Atom2 & Bond length $(\AA)$ & BVS \\
\hline $\mathrm{Mgl}_{\mathrm{C}}-\mathrm{O} 1,2$ & $2.0694(10)$ & 0.36 \\
\hline $\mathrm{Mgl}_{\mathrm{C}}-\mathrm{O} 1,2$ & $2.0694(10)$ & 0.36 \\
\hline $\mathrm{Mgl}_{\mathrm{C}}-\mathrm{O} 1,1$ & $2.0908(10)$ & 0.34 \\
\hline $\mathrm{Mg1}_{\mathrm{C}}-\mathrm{O} 1,1$ & $2.0908(10)$ & 0.34 \\
\hline $\mathrm{Mgl}_{\mathrm{C}}-\mathrm{O} 1,4$ & $2.1258(10)$ & 0.31 \\
\hline $\mathrm{Mg1}_{\mathrm{C}}-\mathrm{O} 1,4$ & $2.1258(10)$ & 0.31 \\
\hline Mean & 2.095 & 2.02 \\
\hline $\mathrm{Mg1}_{\mathrm{N}}-\mathrm{O} 2,2$ & $2.0700(10)$ & 0.36 \\
\hline $\mathrm{Mgl}_{\mathrm{N}}-\mathrm{O} 1,2$ & $2.0853(10)$ & 0.35 \\
\hline $\mathrm{Mg1}_{\mathrm{N}}-\mathrm{O} 2,1$ & $2.1023(11)$ & 0.33 \\
\hline $\mathrm{Mg1}_{\mathrm{N}}-\mathrm{O} 1,1$ & $2.1032(11)$ & 0.33 \\
\hline $\mathrm{Mgl}_{\mathrm{N}}-\mathrm{O} 1,3$ & $2.1165(10)$ & 0.32 \\
\hline $\mathrm{Mg1}_{\mathrm{N}}-\mathrm{O} 2,3$ & $2.1345(10)$ & 0.30 \\
\hline Mean & 2.102 & 1.99 \\
\hline $\mathrm{Mg}_{5}-\mathrm{O} 1,3$ & $2.0284(11)$ & 0.40 \\
\hline $\mathrm{Mg}_{5}-\mathrm{O} 2,2$ & $2.0543(10)$ & 0.38 \\
\hline $\mathrm{Mg} 2_{5}-\mathrm{O} / \mathrm{F}^{*}$ & $2.0572(11)$ & 0.35 \\
\hline $\mathrm{Mg}_{2}-\mathrm{O} 2,1$ & $2.1731(10)$ & 0.27 \\
\hline $\mathrm{Mg}_{5}-\mathrm{O} 2,3$ & $2.1855(11)$ & 0.26 \\
\hline $\mathrm{Mg}_{5}-\mathrm{O} 2,4$ & $2.2087(11)$ & 0.25 \\
\hline Mean & 2.12 & 1.91 \\
\hline $\mathrm{Mg}_{6}-\mathrm{O} 1,2$ & $2.0514(10)$ & 0.38 \\
\hline $\mathrm{Mg} 2_{6}-\mathrm{O} 1,4$ & $2.0549(11)$ & 0.38 \\
\hline $\mathrm{Mg} 2_{6}-\mathrm{O} 2,3$ & $2.0677(11)$ & 0.36 \\
\hline $\mathrm{Mg}_{6}-\mathrm{O} 1,1$ & $2.1763(11)$ & 0.27 \\
\hline $\mathrm{Mg}_{6}-\mathrm{O} 1,3$ & 2.1954(11) & 0.26 \\
\hline $\mathrm{Mg}_{6}-\mathrm{O} 1,4$ & $2.2337(11)$ & 0.23 \\
\hline Mean & 2.130 & 1.88 \\
\hline Mg3/Ti3-O2,4 & $2.0002(11)$ & 0.44 \\
\hline $\mathrm{Mg} 3 / \mathrm{Ti} 3-\mathrm{O} / \mathrm{F}^{*}$ & $2.0197(10)$ & 0.38 \\
\hline $\mathrm{Mg} 3 / \mathrm{Ti} 3-\mathrm{O} / \mathrm{F}^{*}$ & $2.0393(10)$ & 0.37 \\
\hline $\mathrm{Mg} 3 / \mathrm{Ti} 3-\mathrm{O} 2,4$ & $2.1204(11)$ & 0.31 \\
\hline Mg3/Ti3-O2,1 & $2.1239(11)$ & 0.31 \\
\hline Mg3/Ti3-O2,2 & $2.1879(11)$ & 0.26 \\
\hline Mean & 2.082 & 2.07 \\
\hline Sil-O1,1 & $1.6127(10)$ & 1.03 \\
\hline Sil-O1,2 & $1.6512(10)$ & 0.93 \\
\hline Sil-O1,3 & $1.6347(10)$ & 0.97 \\
\hline Sil-O1,4 & $1.6344(10)$ & 0.97 \\
\hline Mean & 1.633 & 3.90 \\
\hline $\mathrm{Si} 2-\mathrm{O} 2,1$ & $1.6127(10)$ & 1.03 \\
\hline $\mathrm{Si} 2-\mathrm{O} 2,2$ & $1.6426(10)$ & 0.95 \\
\hline $\mathrm{Si} 2-\mathrm{O} 2,3$ & $1.6380(10)$ & 0.96 \\
\hline $\mathrm{Si} 2-\mathrm{O} 2,4$ & $1.6381(10)$ & 0.96 \\
\hline Mean & 1.633 & 3.90 \\
\hline
\end{tabular}

TABle 5: Continued.

\begin{tabular}{|c|c|c|}
\hline Atom1-Atom2 & Bond length $(\AA)$ & BVS \\
\hline \multicolumn{3}{|c|}{ Hydrogen bond } \\
\hline $\mathrm{O}-\mathrm{H}$ & $0.99(4)$ & \\
\hline $\mathrm{O} / \mathrm{F} \cdots \mathrm{O} / \mathrm{F}$ & 2.976 & \\
\hline $\mathrm{O} / \mathrm{F}-\mathrm{H}-\mathrm{O} / \mathrm{F}$ & $172.49^{\circ}$ & \\
\hline $\mathrm{H} \cdots \mathrm{O} / \mathrm{F}$ & 1.992 & \\
\hline $\mathrm{H} \cdots \mathrm{H}$ & 1.018 & \\
\hline \multicolumn{3}{|c|}{$\begin{array}{l}\text { BVS (v.u.) for the oxygen atoms: } \mathrm{O} 1,1=1.97 ; \mathrm{O} 1,2=2.02 \\
\mathrm{O} 1,3=1.95, \mathrm{O} 1,4=1.89 ; \mathrm{O} 2,1=1.95 ; \mathrm{O} 2,2=1.95 ; \mathrm{O} 2,3= \\
1.89 ; \mathrm{O} 2,4=1.96 ; \mathrm{O} / \mathrm{F}=1.10\end{array}$} \\
\hline
\end{tabular}

3.3. Raman and FTIR Spectroscopy. Raw single-crystal Raman spectra are displayed in Figure 3. The region below $350 \mathrm{~cm}^{-1}$, corresponding to vibrations of $\mathrm{MO}_{6}$ octahedra [21], contains plethora of weak bands, of which the most intense ones are located at 187, 307, and $321 \mathrm{~cm}^{-1}$. These bands occur at any crystal orientation, together with those at 75 , 84 , and $93 \mathrm{~cm}^{-1}$. Other minor peaks in this region are either broad, having $1 \sigma$ errors greater than $1-2 \mathrm{~cm}^{-1}$, or they are strongly polarization-dependent and do not appear at some crystal orientations.

The region between 400 and $500 \mathrm{~cm}^{-1}$, corresponding to vibrations of $\mathrm{M}-\mathrm{OH}$ units [7] contains only one weak, polarization-insensitive band at $431 \mathrm{~cm}^{-1}$. In contrast, strong vibrations occur between 500 and $700 \mathrm{~cm}^{-1}$, corresponding to the $M-\mathrm{O}$ stretching vibrations [41] and asymmetric bending vibrations of $\left(\mathrm{SiO}_{4}\right)^{4-}$ tetrahedra $[21,42]$. These bands exhibit a strong polarization effect. The band component analysis revealed that two small bands at 545 and $586 \mathrm{~cm}^{-1}$ which appear at the maximum height of the $608 \mathrm{~cm}^{-1}$ band are doublets, composed of 539,550, and $577,590 \mathrm{~cm}^{-1}$ bands, respectively. These doublets are discernible only when the $608 \mathrm{~cm}^{-1}$ band is strongly reduced.

The region between $650-1100 \mathrm{~cm}^{-1}$ contains the most intense bands, thus yielding the fingerprint pattern for the humite-group minerals [21]. The bands at $800-1000 \mathrm{~cm}^{-1}$ are assigned to symmetric or asymmetric stretching of $\left(\mathrm{SiO}_{4}\right)^{4-}$ tetrahedra $[24,42]$, while those between 700 and $800 \mathrm{~cm}^{-1}$ are attributed to a $\mathrm{M}-\mathrm{OH}$ bending [42-44]. A band pair at 650 and $690 \mathrm{~cm}^{-1}$ likely associated with $\mathrm{Fe}-\mathrm{O}$ lattice vibrations [45] is missing in our samples. Band component analysis shows that the broad band at $748 \mathrm{~cm}^{-1}$ consists of two bands centred at 740 and $757 \mathrm{~cm}^{-1}$, while the single band at $786 \mathrm{~cm}^{-1}$ occurs at any orientation. The triplet consisting of 832,845 and $862 \mathrm{~cm}^{-1}$ bands is typical of clinohumite, humite and chondrodite, but small hidden peaks at 810 and $876 \mathrm{~cm}^{-1}$ on both flanks of the triplet were revealed only in clinohumite [21].

The fundamental $\mathrm{OH}$-stretching vibration region exhibits a doublet around $3400 \mathrm{~cm}^{-1}$ and a triplet extending from 3560 to $3580 \mathrm{~cm}^{-1}$. The two well-separated groups of 


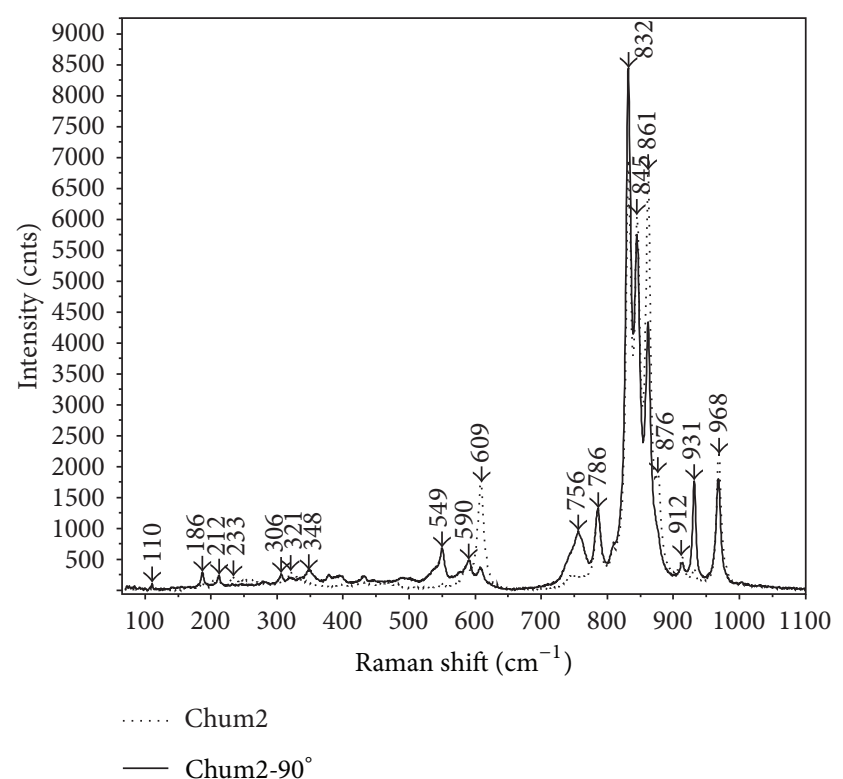

(a)

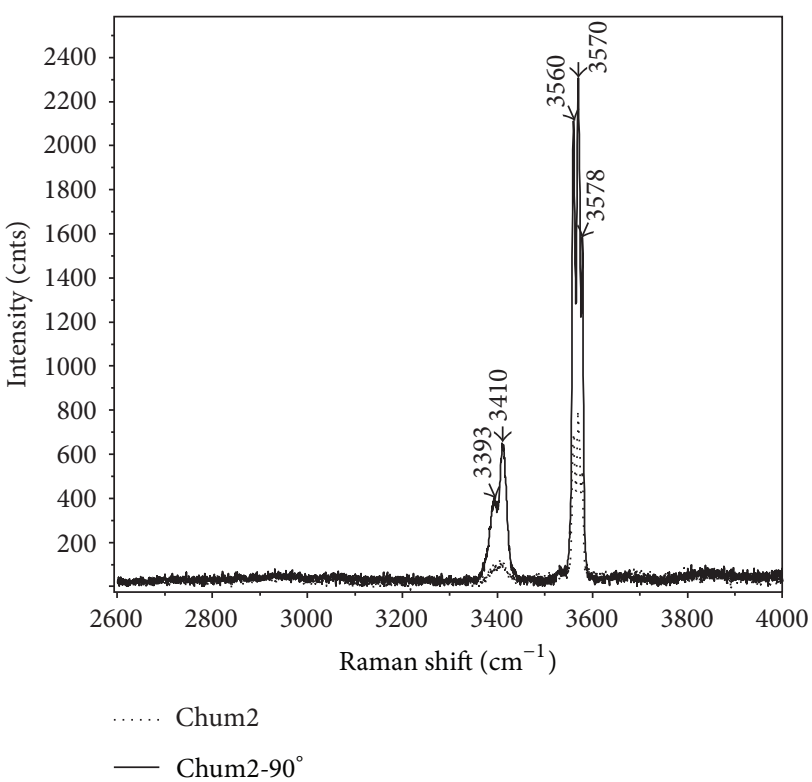

(b)

FIGURE 3: Baseline-corrected raw Raman spectra of hydroxylclinohumite from Vietnam illustrating strong polarization effect on the bands intensity.

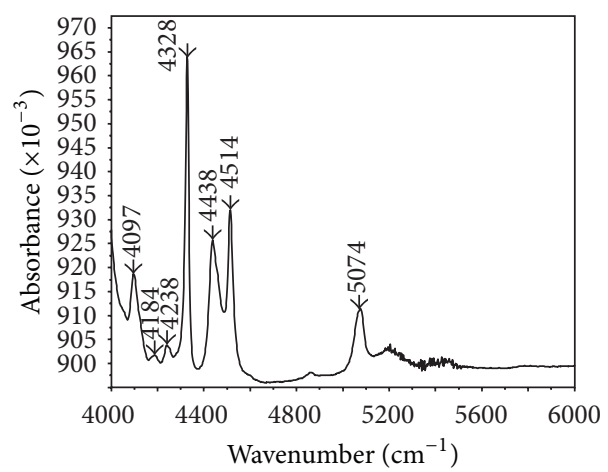

(a)

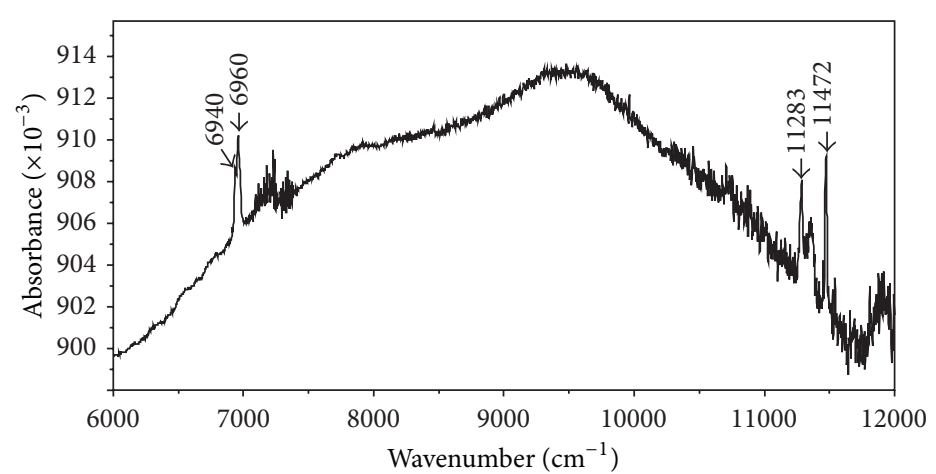

(b)

FIGURE 4: Raw DRIFT FTIR spectrum of hydroxylclinohumite powder.

hydroxyl bands are typical of all natural humite-group minerals except for norbergite and also for hydrated olivine [14, 17, 42]. Band component analysis showed two overlapping bands centred at 3392 and $3412 \mathrm{~cm}^{-1}$ for the low-frequency region, as well as three sharp maxima at 3560, 3570, and $3579 \mathrm{~cm}^{-1}$ in the high-frequency bands. All of these bands are also infrared-active. No Raman-active modes were observed between 4000 and $5000 \mathrm{~cm}^{-1}$.

In spite of relatively high $r^{2}$ correlation factors $(0.992-$ 0.997) achieved for the whole segment of the Raman spectrum at $3300-3700 \mathrm{~cm}^{-1}$, the peak fitting leaves a relatively high number of spots outside the $2 \sigma$ or even $3 \sigma$ probability levels. Particularly the 3560 and $3570 \mathrm{~cm}^{-1}$ bands are obviously skewed to their right sides. Component analysis reveals that these bands are in fact doublets. The band at $3560 \mathrm{~cm}^{-1}$ consists of two components centred at 3559 and $3562 \mathrm{~cm}^{-1}$, while that at $3570 \mathrm{~cm}^{-1}$ consists of two modes centred at 3569 and $3574 \mathrm{~cm}^{-1}$. The observed number of bands is minimal, and a greater number of components substantially improve statistical parameters of deconvolution. For instance, Ye et al. [45] decomposed the two major 3552 and $3560 \mathrm{~cm}^{-1}$ bands in synthetic hydroxylclinohumites to as much as 5 components. It is also worth noting that two small but distinct bands at 3500 and $3608 \mathrm{~cm}^{-1}$ observed in both synthetic pure $\mathrm{Mg}$ - and Fe-bearing hydroxylclinohumites (ibid.) are missing in the hydroxylclinohumite from Vietnam.

Near- and mid-FTIR spectra of hydroxylclinohumite crystals and powder exhibited major bands at 3393, 3415, 3558, 3568, 3577, 4097, 4328, 4438, 4514, and $5074 \mathrm{~cm}^{-1}$ and minor bands near 3528, 3692, 4184 and $4238 \mathrm{~cm}^{-1}$ with little shoulder near $4249 \mathrm{~cm}^{-1}$ (Figures 4 and 5). The band near $4097 \mathrm{~cm}^{-1}$ belongs to a combination of $\mathrm{OH}$-stretching and $\mathrm{Mg}-\mathrm{OH}$ bending modes, while that at $4184 \mathrm{~cm}^{-1}$ is attributed to combination of $v(\mathrm{OH})$ and $v(\mathrm{Mg}-\mathrm{O})$ modes 


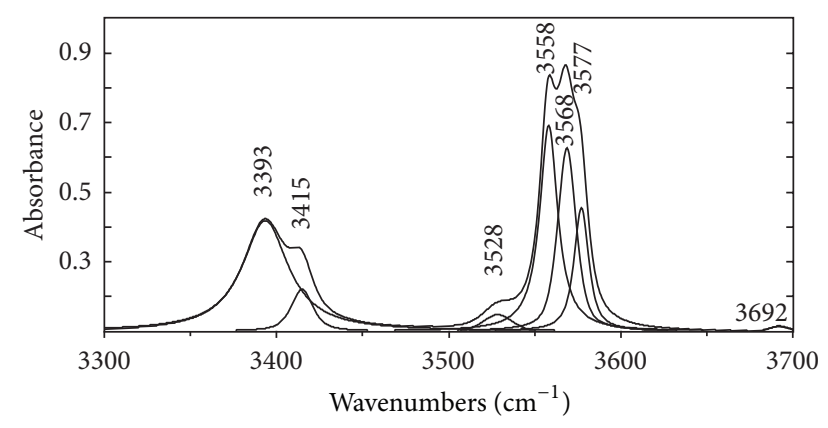

FIGURE 5: Band-component analysis of a DRIFT FTIR spectrum of hydroxylclinohumite powder in the $\mathrm{OH}$-stretching region.

[22]. Minor Fe admixture in the clinohumite structure is documented by two low-intensity bands near $4238 \mathrm{~cm}^{-1}$ and $4249 \mathrm{~cm}^{-1}$ caused by $\mathrm{Fe}-\mathrm{O}$ vibrations $\left(\nu_{\mathrm{OH}}+\delta_{\mathrm{Fe}-\mathrm{OH}}\right)$. The presence of this minor band demonstrates an isomorphous substitution of $\mathrm{Fe}^{2+}$ for $\mathrm{Mg}^{2+}$ in the $\mathrm{MO}_{6}$ octahedra of clinohumite [46]. The sharp and intense band at $4328 \mathrm{~cm}^{-1}$ reflects the high $\mathrm{Mg}$ content in the structure, comprising the sum of the $\mathrm{OH}$-stretching and the $\mathrm{Mg} 3-\mathrm{OH}$ bending modes [47]. The vibration near $4438 \mathrm{~cm}^{-1}$ together with the associated shoulder near $4458 \mathrm{~cm}^{-1}$ is connected with combinations of $\mathrm{OH}$-stretching vibrations and $\mathrm{Mg}-\mathrm{OH}$ and/or $\mathrm{Fe}-\mathrm{OH}$ bending modes [46]. The appearance of the very high intensive sharp band at $4514 \mathrm{~cm}^{-1}$ was attributed to combination of fundamental bands of the $\mathrm{Si}-\mathrm{OH}$ bonding [48], while the band near $5074 \mathrm{~cm}^{-1}$ probably corresponds to the combination of $\mathrm{OH}^{-}$and $\mathrm{Si}-\mathrm{OH}$ vibrations [49]. The group of four bands at $6940,6960,11283$, and $11472 \mathrm{~cm}^{-1}$ can be interpreted as the first $\left(2 v_{\mathrm{OH}}\right)$ and the second $\left(3 v_{\mathrm{OH}}\right)$ overtones of the $\mathrm{OH}$-stretching vibration mode. The band component analysis of the FTIR spectrum shows only a minor peak displacement within the $\mathrm{OH}$-stretching region compared to that recorded by Raman.

Two groups of low- and high-frequency absorption bands in the hydroxylclinohumite powder exhibit nonequivalent movement paths on heating accompanied by band broadening and band intensity decrease (Figure 6). The lowfrequency group II bands around $3400 \mathrm{~cm}^{-1}$ tend to move towards higher frequencies with increasing temperature, whereas the high-frequency bands of the group I between 3560 and $3580 \mathrm{~cm}^{-1}$ move in the opposite direction. The observed changes are reversible, and the initial and final spectra taken at room temperature are identical. The total observed shifts are around $+9 \mathrm{~cm}^{-1}$ for the group II and as much as $-15 \mathrm{~cm}^{-1}$ for the $3550 \mathrm{~cm}^{-1}$ band of the group I.

\section{Discussion}

The inferred unit cell parameters and the refined crystal structure for the Vietnamese hydroxylclinohumite are comparable to those of holotype specimen [37, 50], synthetic [51] and other natural clinohumites $[34,36,39]$. The $\mathrm{Mg}^{2+}$ cation is substituted by $\mathrm{Ti}^{4+}, \mathrm{Fe}^{2+}$, and minor $\mathrm{Mn}^{2+}$ as is usual for

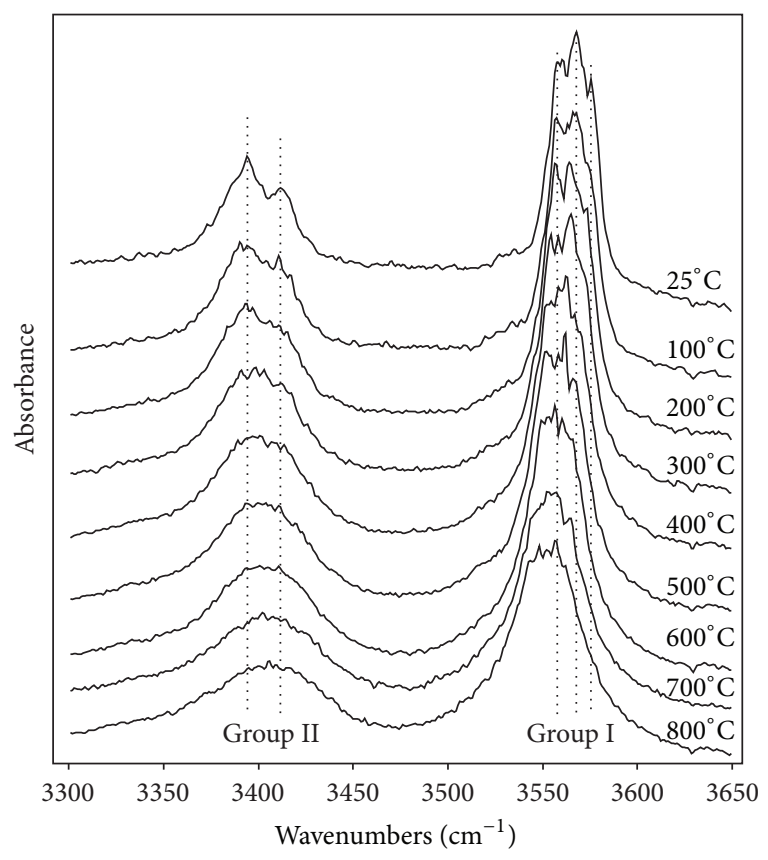

FIGURE 6: Thermal effect on the $\mathrm{OH}$-stretching region in hydroxylclinohumite powder recorded by FTIR.

most clinohumites, for example, [52]. $\mathrm{Ti}^{4+}$-for-Si substitution indicated by small Si-deficiency in electron microprobe analyses, for example, [14], was not confirmed by the crystal structure analysis of the Vietnamese hydroxylclinohumite.

An interesting relationship between concentrations of $\mathrm{Ti}^{4+}$ cations and $\mathrm{F}^{-}$anions and the $\mathrm{Mg} 2_{5}-\mathrm{O} 2,2$ bond length has been observed in two clinohumites studied by Friedrich et al. [34]. The $\mathrm{Mg}_{5}-\mathrm{O} 2,2$ bond length increased with decreasing fluorine and increasing titanium content. This relationship was due to substitution of $\mathrm{Ti}^{4+}$ at the $\mathrm{Mg} 3$ site, which resulted in strengthened $\mathrm{Mg} 3-\mathrm{O} 2,2$ bonds with a bond length of 2.188(1) $\AA$. Our clinohumite with 0.05 a.p.f.u. of $\mathrm{Ti}$ and 1.03 a.p.f.u. of $\mathrm{F}$ exhibits a shorter $\mathrm{Mg} 2_{5}-\mathrm{O} 2,2$ bond corresponding to 2.054(1) $\AA$. The refined Ti content (0.05 a.p.f.u.) lies within the EPMA error margin (0.045 a.p.f.u). The average $\mathrm{Mg}-\mathrm{O}$ bond lengths are consistent with other $\mathrm{F}-$ bearing clinohumites, that confirms previous findings of their independence on the chemical composition ([37] and references therein). The $\mathrm{O}-\mathrm{H}$ bond distance $0.99(4) \AA$ is shorter than that in other clinohumites $[34,38]$, probably due to lower temperature of measurement $(153 \mathrm{~K})$ and/or the presence of fluorine anions, which are stronger hydrogen bond acceptors than $\mathrm{O}^{2-}$.

Of particular interest are the Raman and MIR bands of the $\mathrm{OH}$-stretching vibration region. Libowitzky [53] revealed a correlation of $\mathrm{O}-\mathrm{H}$ stretching frequencies with $\mathrm{O} \cdots \mathrm{O}$ and $\mathrm{H} \cdots \mathrm{O}$ bond lengths. This correlation shows that the $\mathrm{O}-\mathrm{H}$ stretching frequency increases with increasing $d(\mathrm{O} \cdots \mathrm{O})$ bond length. Very strong $\mathrm{H}$-bonds appear in the lowfrequency part (below $\left.1600 \mathrm{~cm}^{-1}\right)$ with $d(\mathrm{O} \cdots \mathrm{O})$ values below $2.50 \AA$. Wavenumbers between 1600 and $3200 \mathrm{~cm}^{-1}$ and $\mathrm{O} \cdots \mathrm{O}$ distances between 2.50 and $2.70 \AA$ are assigned 
to strong $\mathrm{H}$-bonds. In contrast, weak $\mathrm{H}$-bonds are characteristically above $3200 \mathrm{~cm}^{-1}$ with $\mathrm{O} \cdots$ O bond lengths of $2.70 \AA$. Hence, our Raman and FTIR investigations clearly classify the H-bonds in the Vietnamese hydroxylclinohumite as weak. This is, however, controversial with the reversible, temperature-induced shift of two $\mathrm{OH}$-stretching vibration regions on heating (Figure 6), which in turn indicates $\mathrm{OH}$ groups engaged in strong $\mathrm{H}$-bonding [54].

The two groups of $\mathrm{OH}$-stretching vibration bands at $3390-3420$ and $3560-3580 \mathrm{~cm}^{-1}$ in the Vietnamese hydroxylclinohumite show similarities with the low- and highfrequency bands in hydrated olivine-the most important water carrier in the mantle, for example, $[18,20]$. The absorption bands at 3395 and $3410 \mathrm{~cm}^{-1}$ in natural clinohumites and chondrodites have been assigned to molecular liquidlike water, silanol groups [14], or hydrogen bonding between $\mathrm{OH}$ groups attached to $\mathrm{Mg}$ in $\mathrm{M}$-site [42]. Adopting the observations of the last authors, the absence of the $3345 \mathrm{~cm}^{-1}$ band in Vietnam clinohumite indicates no hydrogen bonding between $\mathrm{OH}$-groups attached to $\mathrm{Si}$ in the $\mathrm{M}$-site. The strong polarisation effect on the low-energy bands and the reversible band shifting at various temperatures rule out randomly distributed aqueous liquid inclusions [17].

The absence of $\sim 3400 \mathrm{~cm}^{-1}$ bands in the Raman spectra of chemically pure synthetic hydroxylclinohumite [23, 45] suggests that the observed low-frequency band group in the Vietnamese hydroxylclinohumite is associated with impurities, for example, Ti, Fe, F, or undetected B-common minor element in natural humite-group minerals [35]. Considering nearly ideal chemical formula of the Vietnamese clinohumite, the substantial boron content can be excluded. Similarly, the effect of $\mathrm{Fe}^{3+}$ point defects (protons coupled with trivalent ions) as observed in strongly oxidised $\mathrm{Fo}_{90}$ olivines [18] cannot account for the low-frequency group II bands due to low total iron content. This conclusion is in agreement with the absence of the group II bands in synthetic Fe-bearing $\mathrm{OH}$-clinohumite [45]. In addition, the effect of fluorine can be also ruled out because the 3390,3400 and $3415 \mathrm{~cm}^{-1}$ bands occur in both F-rich and F-absent Ti-clinohumites [55]. The low-frequency group II bands can be also attributed to water incorporated in $\mathrm{OH}$-planar defects, as described in natural titanian clinohumites and the olivines containing $\mathrm{Ti}$ clinohumite lamellae $[18,56]$. The observed shift of the lowfrequency group II bands to higher frequencies on heating would indicate $\mathrm{OH}$-groups engaged in strong $\mathrm{H}$-bonding, because thermal expansion leads to increasing $\mathrm{OH}-\mathrm{O}$ distance, weakening the $\mathrm{H}$ bonds and shifting the corresponding band positions to higher frequencies [54]. In contrast, the shift of the high-frequency group I bands to lower frequencies in the heated hydroxylclinohumite is reminiscent of that observed in hydrated olivines. The effect was explained by the increasing anharmonicity of the $\mathrm{OH}$-bonds involved in the vacancies on the $\mathrm{Mg}^{2+}$ site [20].

\section{Conclusions}

We provide complete chemical, structural, and spectroscopic characteristics of hydroxylclinohumite from Vietnam, with the chemical formula $4\left[\mathrm{Mg}_{2} \mathrm{SiO}_{4}\right] \cdot\left[(\mathrm{Mg}, \mathrm{Fe}, \mathrm{Ti})(\mathrm{OH}, \mathrm{F})_{2}\right]$ and roughly equal $\mathrm{F} / \mathrm{OH}$ ratio. Apart from the crystal structure data, cell parameters, and element substitutions, we describe a total of 36 Raman and FTIR bands recorded in the spectral range between 50 and $12000 \mathrm{~cm}^{-1}$ and document reversible opposing temperature-induced shift of two groups of lowand high-frequency $\mathrm{OH}$-stretching vibration bands.

\section{Conflict of Interests}

The authors declare that there is no conflict of interests regarding the publication of this paper.

\section{Acknowledgments}

The authors are grateful to Helmar Görls for help with single-crystal data collection, to Gerald Giester and Uwe Kolitsch for helpful comments, and to N. Q. Cuong for geological location of the samples. Establishment of Raman and X-ray Laboratories was supported by the European Regional Development Fund under project of the Centre of Excellence for Integrated Research of the Earth's Geosphere (ITMS-26220120064). Establishment of FTIR Laboratory was supported by the APVV project Solipha (0033/07). The paper benefited from critical reviews of five anonymous reviewers.

\section{References}

[1] J. N. Jones, P. H. Ribbe, and G. V. Gibbs, "Crystal chemistry of the humite minerals," The American Mineralogist, vol. 54, no. 3-4, pp. 391-411, 1969.

[2] B. W. Evans and V. Trommsdorff, "Fluorine hydroxyl titanian clinohumite in Alpine recrystallized garnet peridotite: compositional controls and petrologic significance," The American Journal of Science, vol. 283, pp. 355-369, 1983.

[3] A. I. Okay, "Sapphirine and Ti-clinohumite in ultra-highpressure garnet-pyroxenite and eclogite from Dabie Shan, China," Contributions to Mineralogy and Petrology, vol. 116, no. 1-2, pp. 145-155, 1994.

[4] R. Y. Zhang, J. G. Liou, and B. L. Cong, "Talc-, magnesiteand Ti-clinohumite-bearing ultrahigh-pressure meta-mafic and ultramafic complex in the Dabie mountains, China," Journal of Petrology, vol. 36, no. 4, pp. 1011-1037, 1995.

[5] I. Katayama, A. Muko, T. Iizuka et al., "Dating of zircon from Ticlinohumite-bearing garnet peridotite: implication for timing of mantle metasomatism," Geology, vol. 31, no. 8, pp. 713-716, 2003.

[6] K.-I. Aoki, K. Fujino, and M. Akaogi, “Titanochondrodite and titanoclinohumite derived from the upper mantle in the Buell Park Kimberlite, Arizona, USA," Contributions to Mineralogy and Petrology, vol. 56, no. 3, pp. 243-253, 1976.

[7] M. Akaogi and S.-I. Akimoto, "Infrared spectra of high-pressure hydrous silicates in the system $\mathrm{MgO}-\mathrm{SiO}_{2}-\mathrm{H}_{2} \mathrm{O}$," Physics and Chemistry of Minerals, vol. 13, no. 3, pp. 161-164, 1986.

[8] R. Stalder and P. Ulmer, "Phase relations of a serpentine composition between 5 and $14 \mathrm{GPa}$ : significance of clinohumite and phase $\mathrm{E}$ as water carriers into the transition zone," Contributions to Mineralogy and Petrology, vol. 140, no. 6, pp. 670-679, 2001. 
[9] C. Bhattacharyya, "Clinohumite marble from Vemali, Srikakulam District, Andhra Pradesh, India," Mineralogical Magazine, vol. 39, pp. 727-729, 1974.

[10] J. M. Rice, "Phase equilibria involving humite minerals in impure dolomitic limestones. Part I: Calculated stability of clinohumite," Contributions to Mineralogy and Petrology, vol. 71, no. 3, pp. 219-235, 1980.

[11] K. Bucher-Nurminen, "On the mechanism of contact aureole formation in dolomitic country rock by the Adamello intrusion (northern Italy)," The American Mineralogist, vol. 67, no. 11-12, pp. 1101-1117, 1982.

[12] K. Ehlers and G. Hoinkes, "Titanian chondrodite and clinohumite in marbles from the Ötztal crystalline basement," Mineralogy and Petrology, vol. 36, no. 1, pp. 13-25, 1987.

[13] R. Gieré, "Titanian clinohumite and geikielite in marbles from the Bergell contact aureole," Contributions to Mineralogy and Petrology, vol. 96, no. 4, pp. 496-502, 1987.

[14] M. Satish-Kumar and N. Niimi, "Fluorine-rich clinohumite from Ambasamudram marbles, southern India: mineralogical and preliminary FTIR spectroscopic characterization," Mineralogical Magazine, vol. 62, no. 4, pp. 509-519, 1998.

[15] R. Čopjaková, S. Vrána, S. Houzar et al., “Zirkonolit, baddeleyit a geikielit $\mathrm{v}$ klinohumit-spinel-forsteritových mramorech $\mathrm{z}$ okolí Horažd'ovic a Prachatic, jihozápadní Čechy," Acta Musei Moraviae Scientiae Geologicae, vol. 93, pp. 37-51, 2008.

[16] M. Kitamura, S. Kondoh, N. Morimoto, G. H. Miller, G. R. Rossman, and A. Putnis, "Planar OH-bearing defects in mantle olivine," Nature, vol. 328, no. 6126, pp. 143-145, 1988.

[17] S. S. Matsyuk and K. Langer, "Hydroxyl in olivines from mantle xenoliths in kimberlites of the Siberian platform," Contributions to Mineralogy and Petrology, vol. 147, no. 4, pp. 413-437, 2004.

[18] A. J. Berry, J. Hermann, H. S. C. O’Neill, and G. J. Foran, "Fingerprinting the water site in mantle olivine," Geology, vol. 33, no. 11, pp. 869-872, 2005.

[19] E. Balan, J. Ingrin, S. Delattre, I. Kovács, and M. Blanchard, "Theoretical infrared spectrum of $\mathrm{OH}$-defects in forsterite," European Journal of Mineralogy, vol. 23, no. 3, pp. 285-292, 2011.

[20] X.-Z. Yang and H. Keppler, "In-situ infrared spectra of $\mathrm{OH}$ in olivine to $1100^{\circ} \mathrm{C}$," The American Mineralogist, vol. 96, no. 2-3, pp. 451-454, 2011.

[21] R. L. Frost, S. J. Palmer, J. M. Bouzaid, and B. J. Reddy, "A Raman spectroscopic study of humite minerals," Journal of Raman Spectroscopy, vol. 38, no. 1, pp. 68-77, 2007.

[22] R. L. Frost, S. J. Palmer, and B. J. Reddy, "Near-infrared and mid-IR spectroscopy of selected humite minerals," Vibrational Spectroscopy, vol. 44, no. 1, pp. 154-161, 2007.

[23] C.-C. Lin, L. G. Liu, T. P. Mernagh, and T. Irifune, "Raman spectroscopic study of hydroxyl-clinohumite at various pressures and temperatures," Physics and Chemistry of Minerals, vol. 27, no. 5, pp. 320-331, 2000.

[24] Z. Liu, G. A. Lager, R. J. Hemley, and N. L. Ross, "Synchrotron infrared spectroscopy of $\mathrm{OH}$-chondrodite and $\mathrm{OH}$-clinohumite at high pressure," The American Mineralogist, vol. 88, no. 10, pp. 1412-1415, 2003.

[25] V. Garnier, G. Giuliani, D. Ohnenstetter et al., "Marble-hosted ruby deposits from Central and Southeast Asia: towards a new genetic model," Ore Geology Reviews, vol. 34, no. 1-2, pp. 169191, 2008.

[26] L. T. T. Huong, T. Häger, W. Hofmeister et al., "Gemstones from Vietnam: an update," Gems and Gemology, vol. 48, pp. 158-176, 2012.
[27] V. Garnier, G. Giuliani, H. Maluski et al., "Ar-Ar ages in phlogopites from marble-hosted ruby deposits in northern Vietnam: evidence for Cenozoic ruby formation," Chemical Geology, vol. 188, no. 1-2, pp. 33-49, 2002.

[28] G. Giuliani, J. Dubessy, D. Banks et al., " $\mathrm{CO}_{2}-\mathrm{H}_{2} \mathrm{~S}-\mathrm{COS}-\mathrm{S}_{8}$ $\mathrm{AlO}(\mathrm{OH})$-bearing fluid inclusions in ruby from marble-hosted deposits in Luc Yen area, North Vietnam," Chemical Geology, vol. 194, no. 1-3, pp. 167-185, 2003.

[29] Š. Sliacka, Genesis of ruby from Vietnam [M.S. thesis], Comenius University, Bratislava, Slovakia, 2009.

[30] J. L. Pouchou and F. Pichoir, "Un nouveau modèle de calcul pour la microanalyse quantitative par spectrométrie de rayons X. Partie II: application à l'analyse d'échantillons hétérogènes en profondeur," Recherche Aérospatiale, vol. 5, pp. 349-367, 1984.

[31] COLLECT, "Data Collection Software," Nonius B.V., Netherlands, 1998.

[32] Z. Otwinowski, D. Borek, W. Majewski, and W. Minor, "Multiparametric scaling of diffraction intensities," Acta Crystallographica A, vol. 59, no. 3, pp. 228-234, 2003.

[33] G. M. Sheldrick, "A short history of SHELX," Acta Crystallographica A, vol. 64, no. 1, pp. 112-122, 2007.

[34] A. Friedrich, G. A. Lager, M. Kunz, B. C. Chakoumakos, J. R. Smyth, and A. J. Schultz, "Temperature-dependent singlecrystal neutron diffraction study of natural chondrodite and clinohumites," The American Mineralogist, vol. 86, no. 9, pp. 981-989, 2001.

[35] L. Ottolini, F. Cámara, and S. Bigi, "An investigation of matrix effects in the analysis of fluorine in humite-group minerals by EMPA, SIMS, and SREF," The American Mineralogist, vol. 85, no. 1, pp. 89-102, 2000.

[36] K. Robinson, G. V. Gibbs, and P. H. Ribbe, "The crystal structures of the humite minerals. IV. Clinohumite and titanoclinohumite," The American Mineralogist, vol. 58, pp. 43-49, 1973.

[37] G. Ferraris, M. Prencipe, E. V. Sokolova, V. M. Gekimyants, and E. M. Spiridonov, "Hydroxylclinohumite, a new member of the humite group: twinning, crystal structure and crystal chemistry of the clinohumite subgroup," Zeitschrift für Kristallographie, vol. 215, no. 3, pp. 169-173, 2000.

[38] K. Fujino and Y. Takéuchi, "Crystal chemistry of titanian chondrodite and titanian clinohumite of high-pressure origin," The American Mineralogist, vol. 63, pp. 535-543, 1978.

[39] A. N. Platonov, K. Langer, M. Wildner, E. V. Polshin, and S. S. Matsyuk, "The crystal chemistry of the humite minerals: spectroscopic studies and structure refinement of an unusual iron-rich clinohumite," Zeitschrift für Kristallographie, vol. 216, no. 3, pp. 154-164, 2001.

[40] V. Kocman and J. Rucklidge, "The crystal structure of a titaniferous clinohumite," Canadian Mineralogist, vol. 12, pp. 39-45, 1973.

[41] S. Palmer, B. Jagannadha Reddy, and R. L. Frost, "Application of UV-Vis, near-infrared and mid-infrared spectroscopy to the study of Mn-bearing humites," Polyhedron, vol. 26, no. 2, pp. 524-533, 2007.

[42] P. S. R. Prasad and L. P. Sarma, "A near-infrared spectroscopic study of hydroxyl in natural chondrodite," The American Mineralogist, vol. 89, no. 7, pp. 1056-1060, 2004.

[43] Q. Williams, "A vibrational spectroscopic study of hydrogen in high pressure mineral assemblages," in High-Pressure Research: Application To Earth and Planetary Sciences, Y. Syono and M. H. Manghnani, Eds., pp. 289-296, Terra Scientific Publishing, Tokyo, Japan, 1992. 
[44] H. Cynn, A. M. Hofmeister, P. C. Burnley, and A. Navrotsky, "Thermodynamic properties and hydrogen speciation from vibrational spectra of dense hydrous magnesium silicates," Physics and Chemistry of Minerals, vol. 23, no. 6, pp. 361-376, 1996.

[45] Y. Ye, J. R. Smyth, S. D. Jacobsen et al., "Crystal chemistry, thermal expansion, and Raman spectra of hydroxyl-clinohumite: implications for water in Earth's interior," Contributions to Mineralogy and Petrology, vol. 165, pp. 563-574, 2013.

[46] R. N. Clark, T. King, M. Klefwa et al., "High spectral resolution reflectance spectroscopy of minerals," Geophysical Research, vol. B95, pp. 12653-12680, 1990.

[47] J. Madejová and P. Komadel, "Baseline studies of the clay minerals society source clays: infrared methods," Clays and Clay Minerals, vol. 49, no. 5, pp. 410-432, 2001.

[48] A. K. Kronenberg, "Hydrogen speciation and chemical weakening of quartz," in Silica. Reviews in Mineralogy, P. J. Heaney, C. T. Prewitt, and G. V. Gibbs, Eds., vol. 29, pp. 123-176, Mineralogical Society of America, Washington, DC, USA, 1994.

[49] Y. Ping, R. J. Kirkpatrick, P. Brent, P. F. McMillan, and X. Cong, "Structure of calcium silicate hydrate (C-S-H): near-, mid-, and far-infrared spectroscopy," Journal of the American Ceramic Society, vol. 82, no. 3, pp. 742-748, 1999.

[50] V. M. Gekimyants, E. V. Sokolova, E. M. Spiridonov et al., "Hydroxylclinohumite $\mathrm{Mg}_{9}\left(\mathrm{SiO}_{4}\right)_{4}(\mathrm{OH}, \mathrm{F})_{2}$ : a new mineral of the humite group," Zapiski Vserossiyskogo Mineralogicheskogo Obshchestva, vol. 128, pp. 64-70, 1999 (Russian).

[51] A. J. Berry and M. James, "Refinement of hydrogen positions in synthetic hydroxyl-clinohumite by powder neutron diffraction," The American Mineralogist, vol. 86, no. 1-2, pp. 181-184, 2001.

[52] M. Weiss, Clinohumites: A Field and Experimental Study [Ph.D. thesis], ETH Zürich, 1997.

[53] E. Libowitzky, "Correlation of O-H stretching frequencies and $\mathrm{O}-\mathrm{H}$... O hydrogen bond lengths in minerals," in Hydrogen Bond Research, P. Schuster and P. Wolschann, Eds., pp. 103-115, Springer, Vienna, Austria, 1999.

[54] K. Nakamoto, M. Margoshes, and R. E. Rundle, "Stretching frequencies as a function of distances in hydrogen bonds," Journal of the American Chemical Society, vol. 77, no. 24, pp. 6480-6486, 1955.

[55] K. T. Koga, C. J. Garrido, V. López Sánchez et al., "Correlation between compositional and spectral variations in titanian clinohumite," Abstract \#V41D-1764, American Geophysical Union, Fall Meeting, 2006.

[56] J. Hermann, J. D. Fitz Gerald, N. Malaspina, A. J. Berry, and M. Scambelluri, "OH-bearing planar defects in olivine produced by the breakdown of Ti-rich humite minerals from Dabie Shan (China)," Contributions to Mineralogy and Petrology, vol. 153, no. 4, pp. 417-428, 2007.

[57] R. X. Fischer and E. Tillmanns, "The equivalent isotropic displacement factor," Acta Crystallographica, vol. C44, pp. 775776, 1988.

[58] N. E. Brese and M. O'Keeffe, “Bond-valence parameters for solids," Acta Crystallographica, vol. B47, pp. 192-197, 1991.

[59] I. D. Brown, "Valence: a program for calculating bond valences," Journal of Applied Crystallography, vol. 29, pp. 479-480, 1996.

[60] R. T. Downs and K. L. Bartelmehs, "Computer visualization of temperature and pressure effects on crystal structures," EOS Transactions, AGU Spring Meeting Supplement, vol. 77, no. 17, p. S261, 1996. 

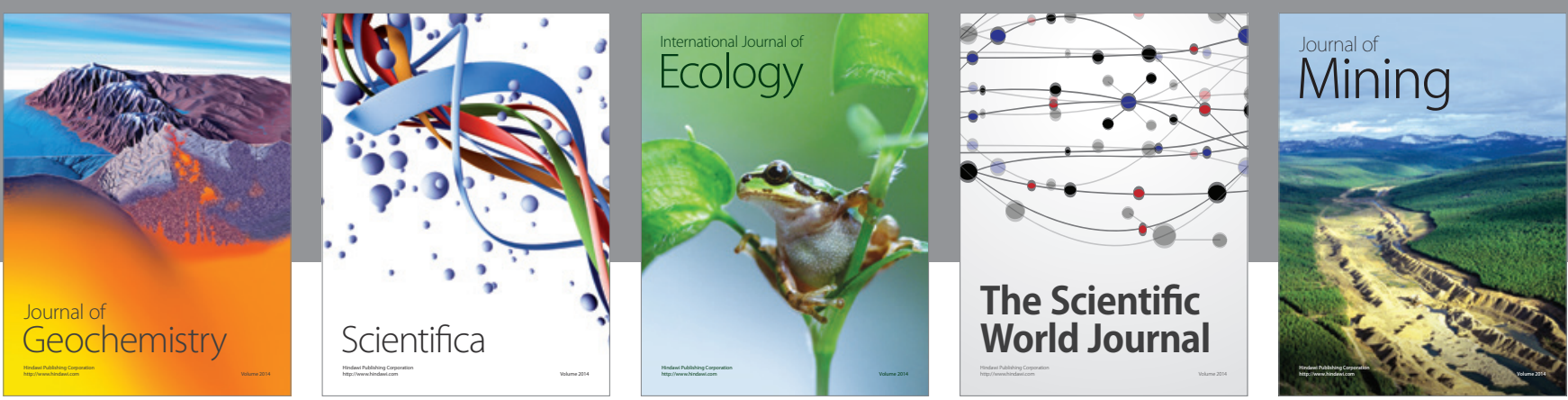

The Scientific World Journal
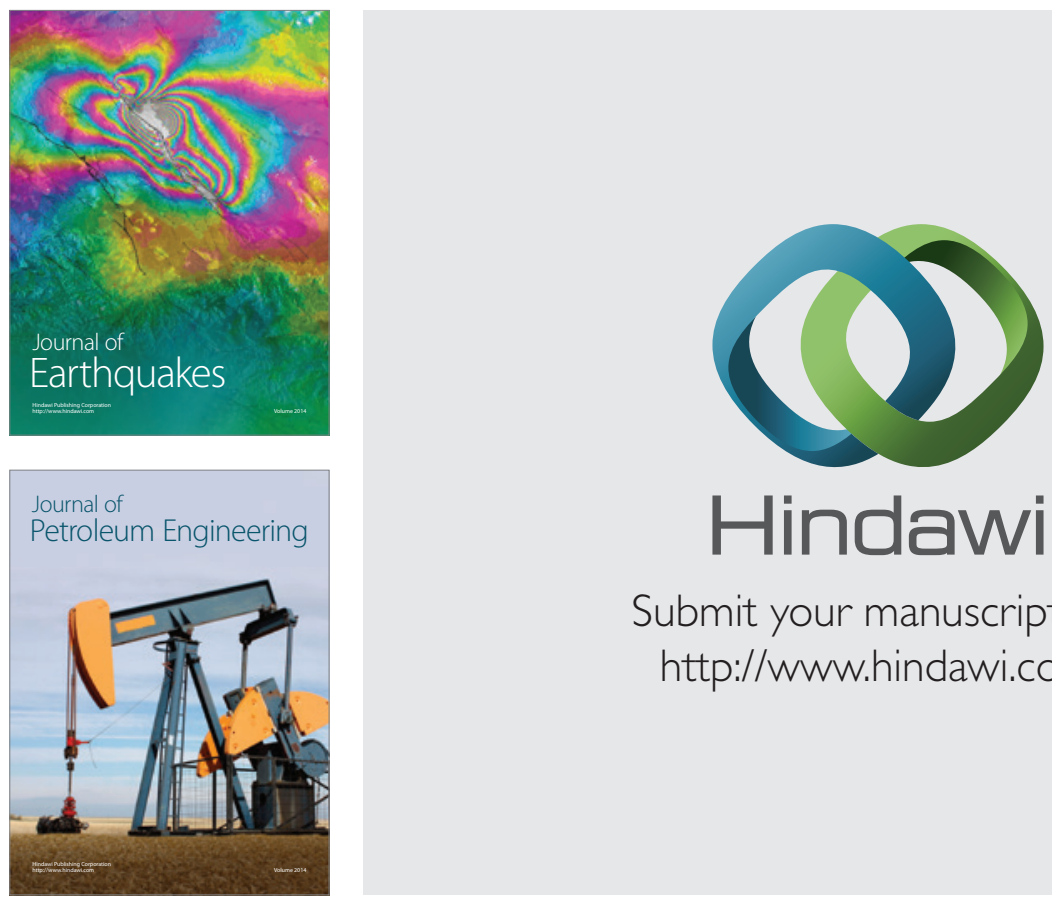

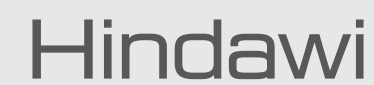

Submit your manuscripts at

http://www.hindawi.com
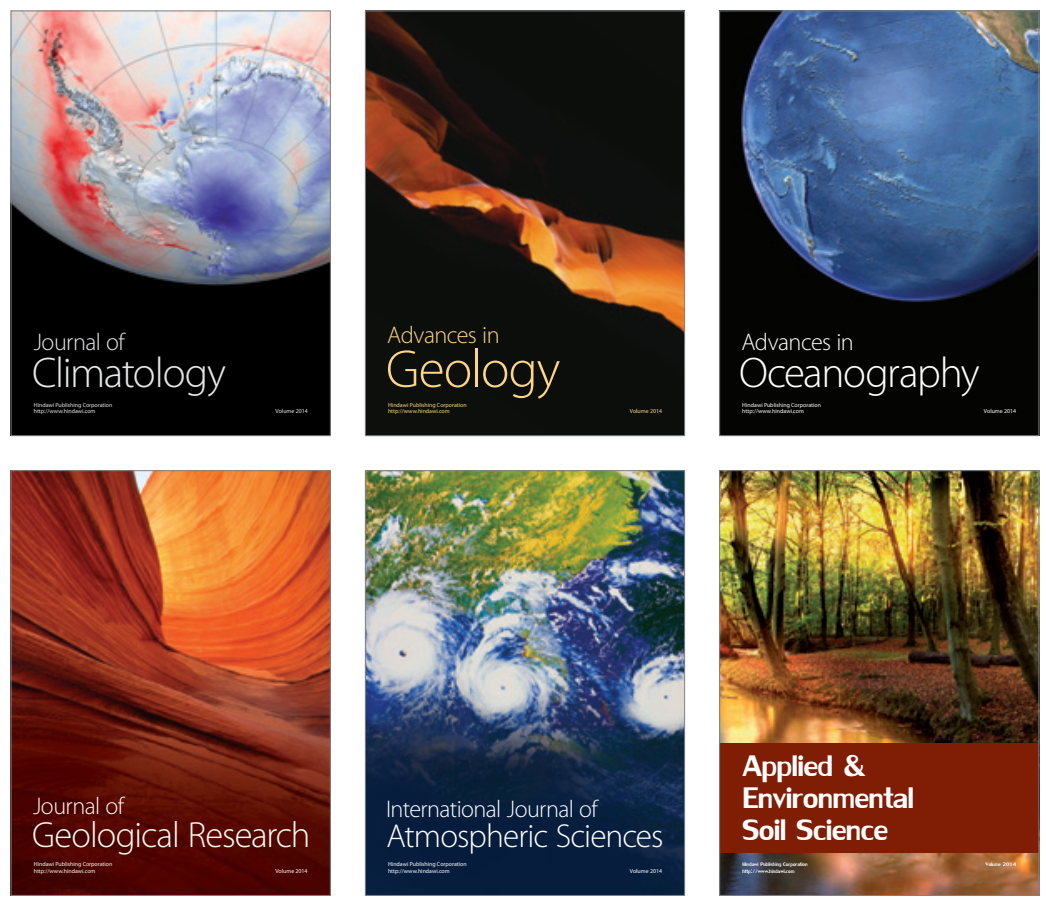
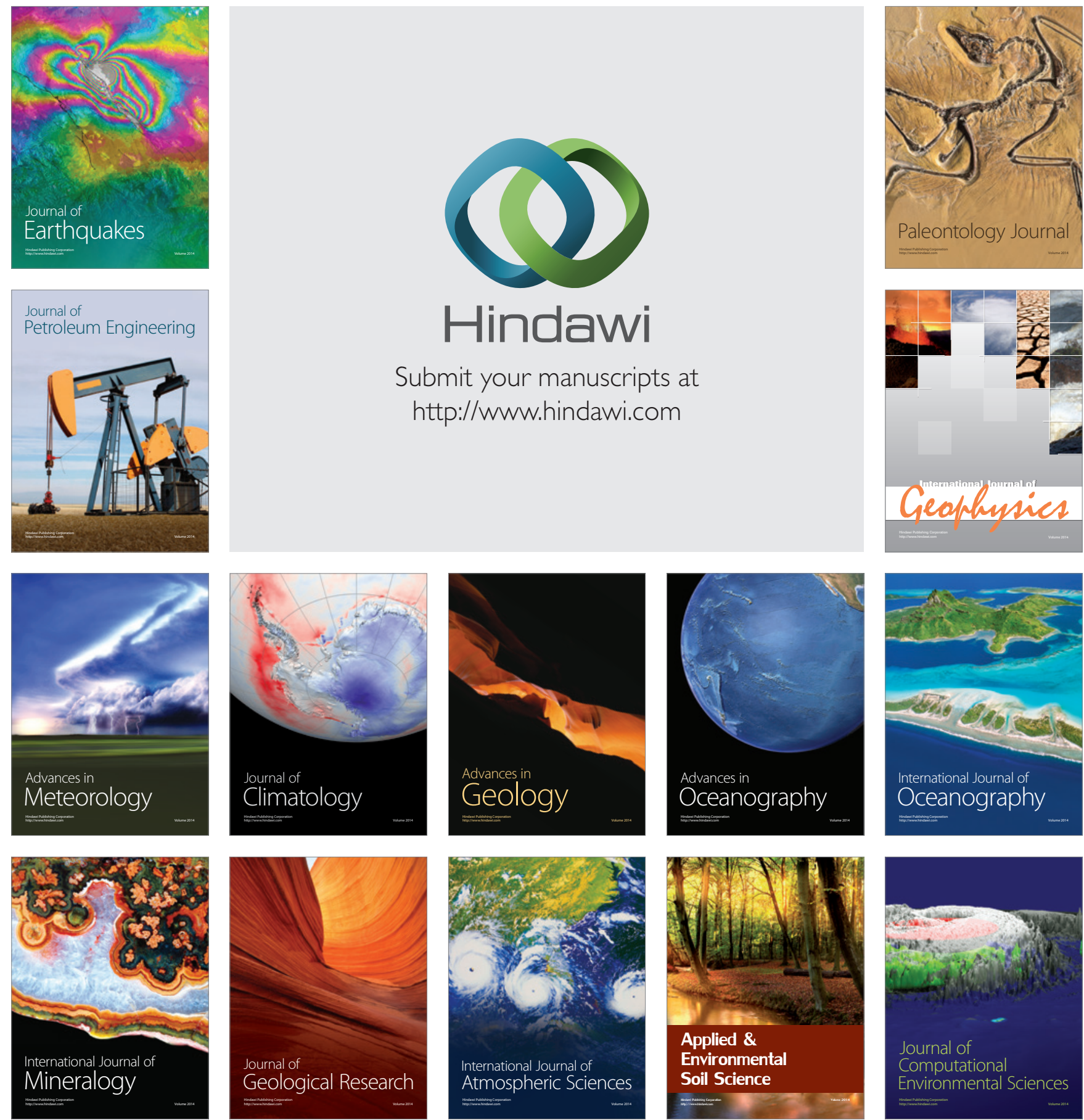